\title{
The Eggs and Early Larvæ of Two Commensal Gastropods, Stilifer stylifer and Odostomia eulimoides.
}

\author{
By \\ Marie V. Lebour, D.Sc. \\ Naturalist at the Plymouth Laboratory. \\ With Plate 1.
}

Stilifer stylifer (Turton) has been recorded from Plymouth many years ago living on Psammechinus miliaris (=Echinus) and Echinus esculentus; also from several other British localities (see Jeffreys, 1867, IV, p. 196). Jeffreys describes the spawn and larvæ hatched from it, but apparently these have never been figured. It had not been rediscovered at Plymouth until 1931 when in August Mr. A. D. Hobson found several specimens of Psammechinus miliaris from deep water beyond the Eddystone with these small commensal molluses on them. In the first lot of about a dozen Psammechinus, three were covered with the spawn of Stilifer, one having one molluse and two having two. In a second lot taken a few days afterwards, five were covered with spawn, one having one mollusc, two having two, and two having three. These were placed in a plunger-jar, but unfortunately most of the Stilifer left the Psammechinus and were presumably eaten by them as pieces of their shells were found. They probably did not like their surroundings. Some of the spawn was removed from the Psammechinus and placed in a fresh plunger-jar with some Nitzschia where some of the larvæ hatched out. A Psammechinus was introduced in the hope that the larvæ might settle down, but they all died after living only a few days.

The eggs were all on the dorsal surface of the Psammechinus, sometimes ten or a dozen egg-sacs on one individual. Each egg-sac is of a more or less three-cornered cushion shape, somewhat rounded, about $1.2 \mathrm{~mm}$. broad and $1.1 \mathrm{~mm}$. high, attached by a narrow stalk to the test of the Psammechinus (Plate 1, Fig. 1), and each sac contained about 60 to 80 eggs. Both egg-sac and eggs were colourless and very transparent. Each egg measured about $0 \cdot 1 \mathrm{~mm}$. long when young, and rather more as the embryo developed, and were roundish or oval in shape. Before hatching the embryonic shell is completely formed. This is a pale brownish horn colour and quite transparent. The foot and velum are well developed and otoliths and eyes are present. On hatching the shell consists of one 
whorl and measures about $0 \cdot 13 \mathrm{~mm}$. across. It is nearly round, the velum having two rounded lobes measuring about $0.12 \mathrm{~mm}$. across. A row of very long cilia edge the margin and a row of much smaller cilia below border the groove leading to the mouth which is very inconspicuous. The foot is short and round, pulled out at the posterior extremity, covered with minute cilia and bearing a very thin operculum. The eyes are very far apart (Plate 1, Fig. 2). In a day or two after hatching, the shell has grown slightly larger, the velum broader, and there is usually one tentacle present (Plate 1, Figs. 3-7). Thus the early larva is a typical veliger and like an ordinary well-developed gastropod. Unfortunately none of them lived more than a few days so that it was impossible to see any changes undergone by its settling down.

Odostomia (Brachystomia) eutimoides Hanley is common in the neighbourhood of Plymouth living on the lamellibranchs Chlamys opercularis and Pecten maximus, usually on the ears. In May and June Mr. A. D. Ritchie gave me several of these and nearly all of them were laying eggs. The eggs are usually on the ears of the shells, but sometimes on the valves. They are laid in irregular gelatinous masses, about a millimetre across, sometimes more and sometimes less, clear and colourless, each mass containing many eggs also clear and colourless (Plate 1, Figs. 8, 9). The eggs are round, measuring about $0.16 \mathrm{~mm}$. across, and are peculiar because the developing embryo at first occupies only the central part, the large space between the embryo and the thick-walled envelope being occupied by a granular fluid. Batches of eggs were obtained on the following dates: $31.5 .31,1.6 .31,11.6 .31,12.6 .31$ (two batches), and others later on in June. In each some of the eggs were only beginning to develop and some were nearly ready to hatch. The eggs were placed in a plunger-jar with Nitzschia and some of them grew up to a certain size, but they all died before the normal dextral shell was formed. However, the larvæ were interesting whilst forming the shell. It probably only lives a short time as a veliger and is not important as a planktonic larva.

It is well known that the genus Odostomia and its allies has an embryonic shell with a sinistral twist, and that the animal is dextral even in the earliest stages. When a certain size has been attained the shell becomes dextral also, the sinistral embryonic shell remaining as the apex, usually placed almost at right angles to the rest. In Odostomia eulimoides this embryonic shell is almost hidden by the later whorls, but in many of its relatives the sinistral apex is clearly seen (Plate 1, Figs. 16-17).

When Odostomia eulimoides hatches it has an almost spherical shell of one whorl, the aperture being to the left. The anus, however, is on the right side, showing that the animal is dextral. There is a short foot drawn out posteriorly, covered with minute cilia and bearing an operculum. The velum has two oval lobes which are nearly circular and the 
eyes 'are far apart. Two otoliths are conspicuous at the base of the foot. The intestinal mass is well differentiated, the digestive gland, stomach, œsophagus, mouth, intestine, anal gland, and anus can all be made out. The newly hatched larva measures about $0.16 \mathrm{~mm}$. across the widest part of the shell and the compact velum measures about the same across. The velar lobes are edged with long cilia and below is a row of much shorter cilia, the two bordering a groove to the mouth. The anal gland is nearly black, as are also the eyes, otherwise the whole animal and shell are clear and colourless (Plate 1, Figs. 10-11). The velum very soon disappears and the animal crawls, but all the crawling stages were abnormal in the plunger-jar and soon died. The shells, however, of those which had two to two and a half whorls were interesting as they showed the transition from a sinistral to a dextral shell. The first two whorls constitute the embryonic shell ; after this a large irregular piece is added which begins on the lower surface of the outer lip. This is an outgrowth which sticks out from the lip and is not at first complete round the whole of the periphery. The more regular growth added later to this forming the dextral shell aperture results in the embryonic shell being at a right angle to the true shell and forming the curious apex characteristic of the shells of this family. A figure is given of the apex of the shell of Eulimella acicula, a related species, but of a different genus, showing this apex in its typical form (Plate 1, Fig. 17).

\section{LITERATURE.}

Jeffreys, G. 1867. British Conchology, Vol. IV, pp. 1-486. 


\section{EXPLANATION OF PLATE.}

(Scale B is six times the scale of A.)

\section{PLATE 1.}

Fla. 1.-Egg-sac of Stilifer stylifer, $1.2 \mathrm{~mm}$. across (scale A).

Scale B $\left\{\begin{array}{l}\text { FIG. 2.-Newly hatched larva, shell } 0 \cdot 13 \mathrm{~mm} \text {. across. } \\ \text { FIG. 3.-Larva a few days old, } 0 \cdot 16 \mathrm{~mm} \text {. across. } \\ \text { Figs. 4-7.-Empty shells of early larvæ. }\end{array}\right.$

FIG. 8.-Portion of egg mass of Odostomia eulimoides (scale A).

Scale B $\left\{\begin{array}{l}\text { FIG. 9.-Egg of Odostomia eulimo } \\ \text { FIG. 10.-Newly hatched larva. } \\ \text { FIG. 11.-Larva a few days old. } \\ \text { FIG. 12.-Empty shell of same. }\end{array}\right.$

Scale A $\left\{\begin{array}{l}\text { Fig. 13.-Newly hatched larva. } \\ \text { Figs. 14-15.-Later shell showing irregular growth at the margin. } \\ \text { Fig. 16.-Apex of adult Odostomia eulimoides. } \\ \text { Fig. 17.-Apex of adult Eulimella acicula. }\end{array}\right.$ 
PLATE 1.
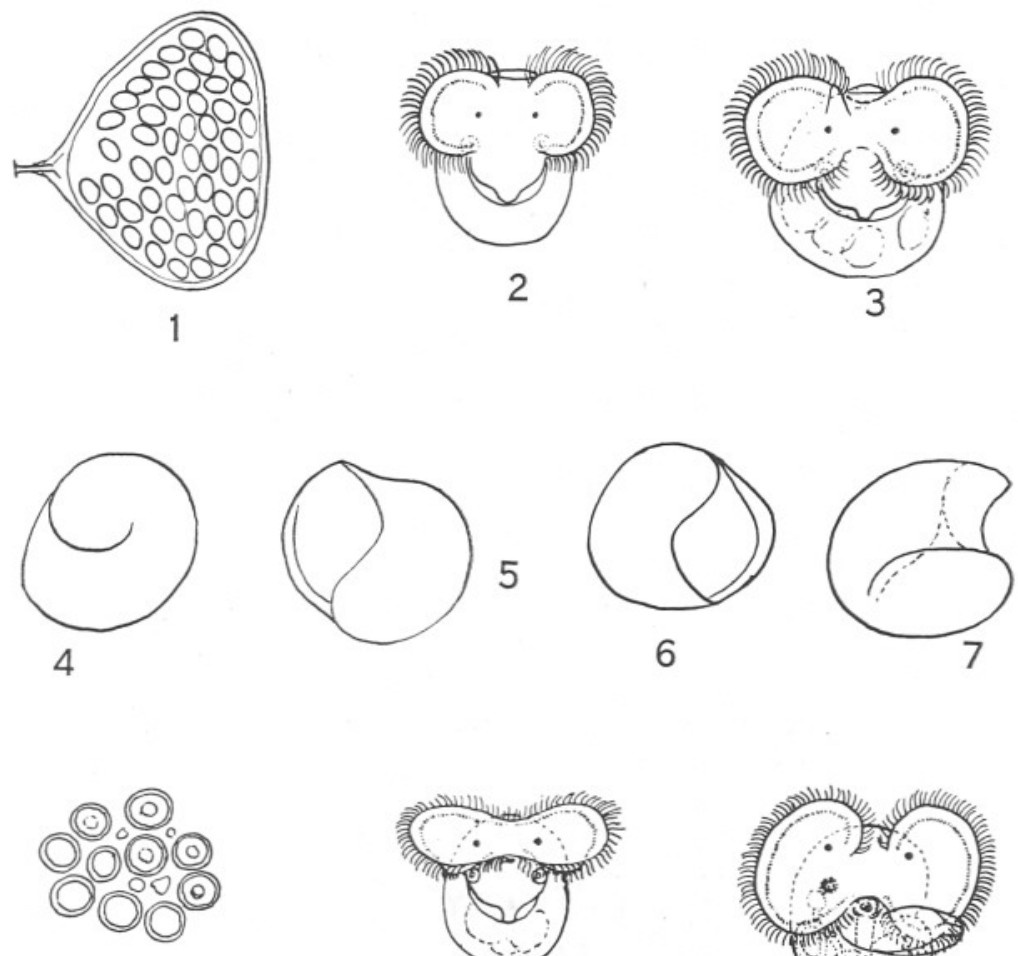

8
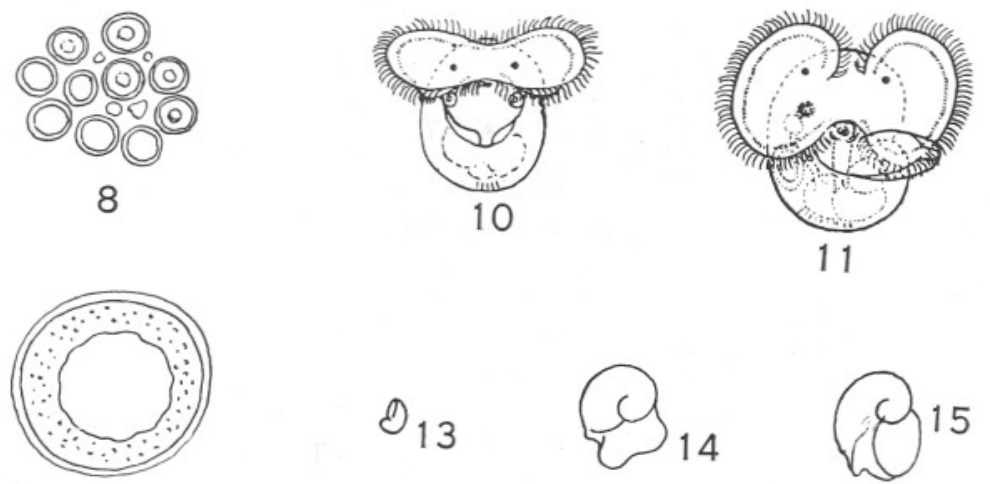

9

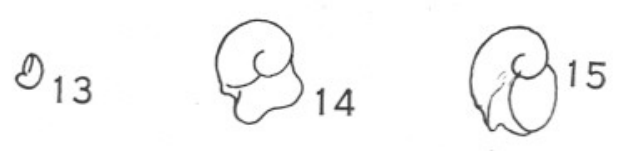

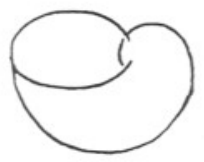

12

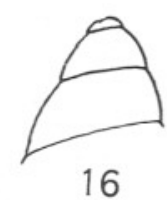

16

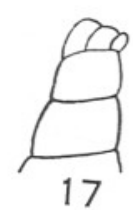


LIBRARY, M.B.A.

PLYMOUTH. 